\title{
“Wayang Kreatif" Performance of Teater Koma and Its Audience
}

\author{
Arthur S. Nalan \\ Institut Seni Budaya Indonesia (ISBI) Bandung \\ Jalan Buahbatu No. 212 Bandung 40265
}

\begin{abstract}
ABSTRAK
Teater Koma merupakan teater modern yang berhasil bertahan selama 40 tahun, dari tahun 1977 sampai sekarang. Perjalanan yang cukup panjang, mendudukkan Teater Koma sebagai teater yang mampu menyajikan pelbagai lakon teater, baik yang berasal dari para dramawan dan sastrawan dunia maupun yang hasil ciptaan sendiri oleh Riantiarno, sebagai pendiri utamanya. Salah satu kumpulan lakon ciptaan Riantiarno adalah lakon-lakon wayang yang dikemas dengan sebutan wayang kreatif. Pertunjukan wayang kreatif Teater Koma ini menjadi objek material yang dipilih untuk didekati dengan paradigma sosiologi seni dan komunikasi seni teater. Pendekatan yang digunakan adalah teori sosiologi seni dari Arnold Hauser dan teori komunikasi efektif dari Gudy Kunst. Adapun hasilnya dapat ditemukan bahwa Teater Koma sebagai teater rakyat perkotaan telah memberikan apresiasi seni kepada publiknya dengan menjalin relasi kepada publiknya melalui berbagai cara, termasuk dengan memanfaatkan media sosial, misalnya memesan tiket secara online. Selain itu, publiknya yang berasal dari segala lapisan masyarakat di Jakarta telah pula dihibur melalui humor-humor kritis yang terdapat dalam setiap pertunjukan wayang kreatiftersebut. Tindakan tersebut membawa interaksi yang berlangsung terus menerus dengan publiknya, sehingga membangun publik yang fanatik terhadap Teater Koma.
\end{abstract}

Kata kunci: Teater Koma, teater rakyat perkotaan, wayang kreatif, publik

\begin{abstract}
Teater Koma is a modern theatre, which has been existing for 40 years since 1977 until today. The group has successfully performed various plays, both written by the world playwrights and by Riantiarno himself as the main founder, an actor, and a play writer. Some of the Riantiarno's plays are puppet plays called wayang kreatif (a creative puppet). The wayang kreatif performance of Teater Koma is the material object of this study, which is approached by the paradigm of the sociology of art and the communication of theatre arts, especialy by applying the theory of Arnorld Hauser's sociology of art and Gudykunst's effective communication theory. The result shows that Teater Koma as an urban folk theatre has been serving its audience with its variety shows promoted through different media, including by utilizing social media, such as booking the ticket online to reach wider audiences. Moreover, its audiences come from different levels of social classes in Jakarta, and they were entertained by sarcastic humors contained in the wayang kreatif performance. These activities maintain the continous interaction between the group and its audiences, so that the grup builds its loyal audiences.
\end{abstract}

Keywords: Teater Koma, urban folk theatre, wayang kreatif, communication, audiences 


\section{INTRODUCTION}

Among theatre groups in Indonesia that still exist up till now is Teater Koma. ${ }^{1}$ The group keeps its activities in producing various performing arts in Jakarta. One of their theatre activities is to perform wayang carangan plays in the form of wayang kreatif. ${ }^{2}$ The name of wayang kreatif is given because it has different style compared to wayang traditional such as the common wayang wong. ${ }^{3}$ In short, Teater Koma is a modern theatre choosing wayang plays as its expression media.

The sustainability of Teater Koma until now is not only because of its performance style but also because of its awareness in "building" its audience. The group has a good communication management that can be understood as a form of responsibility of Teater Koma to its audience. Besides entertainment aspects, the group also pays attention to "signs of local values". The public appreciation to "signs of local wisdom" in the wayang kreatif of Teater Koma production is valued as a significant contribution in theatre world to keep people connected to their cultural roots. Teater Koma intends to give its best play for its audience. However, there are also some criticism coming from audience that Teater Koma "enslaves" itself to popular culture. In this case, the writer argues that a popular culture is considered as a management strategy of Teater Koma to maintain the dynamics between arts and culture in the big city like Jakarta. Teater Koma is fully aware that without adjusting an urban style of Jakartans, they would not stay last with the arts. In this regards, Riantiarno says that Teater Koma is a theater group for urban audience. ${ }^{4}$

\section{METHOD}

In this research activities, the writer applies a qualitative research method. This method is suitable with the characteris- tis of the object material that is chosen for this research, that is wayang kreatif of Teater Koma and its audience. A qualitative method starts with the asumption, theoretical framework, and study about how an individual or a group give meanings to a social or humanity problems (Creswell, 2015: 87). As for techniques for collecting data had been done by several ways: library research, interviews, and observations of performances both through recording and live performance, including several informal coversations with the main reserach resources, Nano Riantiarno and his wife, Ratna Riantiarno. ${ }^{5}$

Furthermore, to analyze how Teater Koma group maintains its relation to its audience in urban society, this paper uses the paradigm of sociology deriving from TS. Kuhn (1970) about the nature of scientific changes. Kuhn believes that scientists work under paradigms, that is general ways to see the world and to decide which scientific works should be done and what kind of theories should be accepted (Abercrombie, 2010: 400). Research on wayang kreatif of Teater Koma has been conducted by the writer continuosly since $2015 .{ }^{6}$ In this research, the writer studies Teater Koma using the paradigm of sociology of art and theatre arts communication. This approach is chosen to fill gaps in the area in which this kind of study has not been done yet.

The paradigms of sociology of arts and theater arts communication are a part of studies chosen by the writer in every research that is conducted. As stated by Stephen K. Sanderson (2010: 20) that sociology is a scientific analysis on society. This field of study divides into two different focuses. First, micro sociologist focuses on analysing social behavior in a group and relatively small social settings. On the contrary, macro sociologist focuses on large social patterns, for example the whole society or larger global links in the society. Generally, 
macro sociologist focuses on comparative and historical perspectives. In this case, the writer takes a position as micro sociologist focusing on analysing social behavior in a group and relatively small settings, that is Teater Koma. Furthermore, the writer is interested to study Teater Koma's functioning as supports for the survival of Teater Koma. This is in line with what Guy Debord (1994) said that a social and natural world is presented as images or performances. "What we are experiencing now is a representation" (Abercombie, 2010: 530). Teater Koma has been showing its movement and responsibility since 1977 in running the representation of "a packed reality" following the change of time and situation. ${ }^{7}$ Therefore, its representation is then communicative with its public especially through its smart, simple, but meaningful humors. It is the meanings that should be delivered to the audience as messages covered with humor, which is considered as an effective way of communication, especially from the characters of panakawan. ${ }^{8}$

\section{RESULTS AND DISCUSSION}

\section{Urban Folk Theatre}

Teater Koma has been 40 years old now since its presence in 1977. It is a quite long journey for a theatre group performs in Jakarta. Jakarta is a melting pot for various ethnic groups in Indonesia for long time, especially in the colonial period until today with all dynamics and variety of its society. Urbanization in the city has been increasing with all dreams and hopes for its newcomers, either those who have good education or not. Teater Koma as urban theatre is fully aware of the impact of this urbanization resulting in multi layers acculturation. The acculturation itself can be understood as a process of enculturalisation through a mix of two cultures or more, which are interrelated and influenced each other. This includes the influence of foreign culture to the society and the emergence of cultural changes happen through a continuos and intensive meeting which influence each other between two different cultural groups (Dagun, 2005: 27). Based on "reading" process of Riantiarno as a playwright, a director, and also an actor, he positions Teater Koma as the urban theatre. In other words, theatre can take a part in the context of acculturation by selecting and creating plays inspired from anywhere to be potential and competitive with variety forms and kinds of performances in Jakarta.

During its move and activities, Teater Koma has positioned the world playwrights and literature, such as Aristopanes, Shakespeare, Bertolt Brecht, Chekov, Mollier, George Bugner, Mankiewitz, Durenmatt, Carl Zuckmayer, Beaumarchais, Emmanuel Robles, Alfred Jarre, Walmiki, Viyasa, Orwell, Bo Shing Hoo become more "grounded" by adapting their works into Indonesian context. Even, Sampek Eng Tay play is adopted from its Chinese clasiccal version of the novel into the local setting of old Betawi, which make it a very different version which far from its original. The Indonesianness that is "caught" by Riantiarno through moments of ethnography, anthropology, sociology, economy, philosophy, communication, urbanization, all becomess "a context" for his adaptation works. Thus, "the local colors" in his works are very strong. Riantiarno always applies the convergent communication for his audience (Nalan, 2017: 39).

Apart from his adaptation works, Riantiarno also creates his own plays deriving from adaptation works, such as a wayang play based on Walmiki and Viyasa's works, and also Bo Shing Hoo's Chinese play. He wrote ten plays of wayang. Seven of them are published in a book entitled Republik Wayang. ${ }^{9}$ Riantiarno also wrote a wayang novel entitled Mahabharata Jawa. ${ }^{10}$ Further- 
more, he also wrote plays that are contextual with the life of Jakarta, such as Opera Julini, Opera Kecoa, and Opera Sembelit.

It is also found in the traditional plays of wayang living in Jakarta, such as wayang wong in which it is handed down from generation to generation as tradition of famous Javanese dance, especially in Yogyakarta. ${ }^{11}$ Wayang wong Bharata group living in Jakarta is originally from Surakarta. In this case, Jakarta as an urban city keeps positioning the traditional performing arts as a place for appreciation for its people. This has been done and supported by the ethnic groups living in the city such as Javanese people who appreciate wayang wong, or Sundanese people who appreciate Sundanese drama, Miss Tjitjih. ${ }^{12}$ Their relation to traditional wayang with the activities of Teater Koma that creates a new tradition of wayang kreatif reveals that the theatre is for urban society, both in traditional and new tradition as Teater Koma did, shows the dynamics of the theatre in urban society, especially in Jakarta. The only significant difference among them is the tradition applied. The plays of wayang wong Bharata and Sundanese drama Miss Tjitjih are applied in a traditional way using oral tradition as a communication language. Meanwhile, in wayang kreatif of Teater Koma its play is written by Riantiarno, consistently, including the urban humor style as one of his distinctive characteristics.

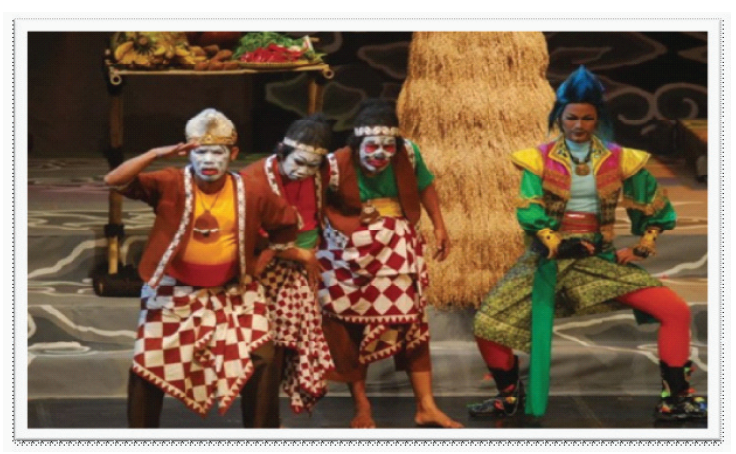

Fig. 1. The scene of Semar Gugat Play (1995) (Teater Koma collection)

\section{Teater Koma and "Wayang Kreatif"}

Teater Koma determines a potential of traditional wayang as its basic creativity. This has cultivated awareness of new tradition of wayang by creating plays wayang kreatif for the theatre performance. Teater Koma through Riantiarno as the writer and the director of the plays has positioned, acted out, and functioned wayang as an effective communication delivering ethnopedagogic values needed by its supporting society or its audience. The effective communication, as stated by Gudykunst in E.M. Griffin (2006: 427), drives to minimalize misunderstanding. He argues that effective communication is to increase one's ability to interprete messages and give meanings of the messages, which is similar to what is transmitted by someone else, or others, which use the same ideas, accuration, precision, and understanding.

Teater Koma makes efforts to build an effective communication in every performance. This can be seen either from their production or in their rehearsal process to obtain a unity between artistic and aesthetic elements. The concept they apply is enak memainkannya (enjoyable) or supaya gayeng (amusing/pleasant) ${ }^{13}$. The performance concept of wayang kreatif is manifested into a performance with full of fun or joke, especially in the plays entitled republik, namely Republik Bagong, Republik Togog, Republik Petruk, Republik Cangik, and Semar Gugat. The Republik world of Teater Koma is a representation of the reality of Indonesia symbolized in the wayang world, where the characters of panakawan gets more portions rather than the Knight/heroes. Those plays represent "people resistance" toward the tyranny of the authorities. This is in line with what Chris Jenks (2004: 122) stated that art has a material basis in the structure and organization of society, in their belief, their productions, and their politic organization. Through the performance of wayang kreatif, 


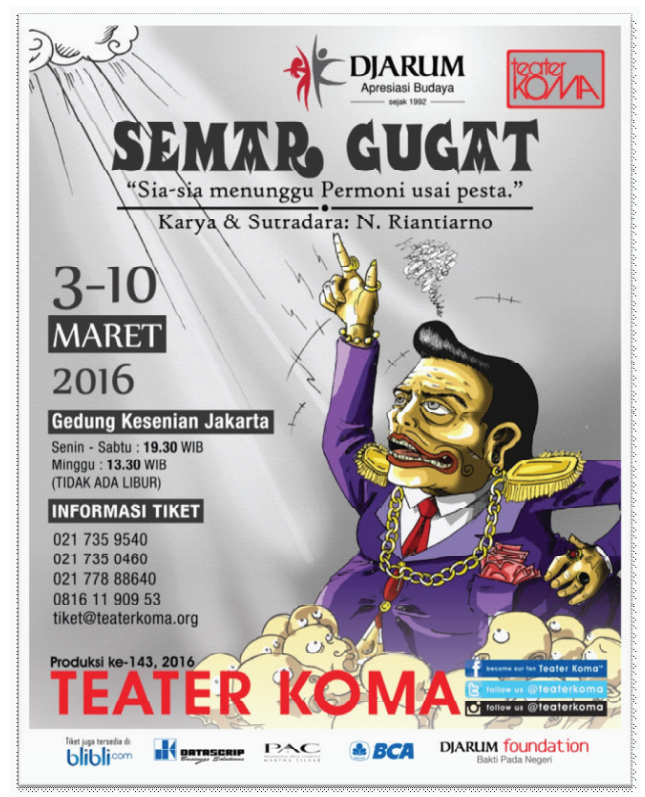

Fig. 2. The Poster of "wayang kreatif" performance entitled Semar Gugat (Teater Koma collection)

Teater Koma, reminds us to the essence of art as stated by Jenks above. Art with material basis means that a traditional wayang as a creative source is developed through creative interpretation of the playwright (in this case Riantiarno). The creative interpretation presents some problems of Indonesian people, which usually become victims of the authorities, in which the power is presented as an ilusion in satire and sarcastic ways, in a satire comedy and humor that full of guyon parikena. ${ }^{14}$ The following is an example of guyon parikena quoted from the dialogue of Semar Gugat play, which can be categorized as sarcasm ${ }^{15}$ :

Banyak satria yang tetap hidup mesti tanpa kepalal Mereka dianugerahi dewa kekuasaan untuk memerintah dunial Akibatnya, mereka semenamena. Ada malah di antara mereka yang di samping tidak punya kepala, juga jantungnya tidak adal Lebih celaka lagi, para Panakawan mereka masih lengkap wujud manusianya dengan jantung dan kepalal Itu kenyataannya (p. 36).

[There are many knights keep living although without their head/ They are bestowed a power to govern the world by the God/ They consequently to do injustice to the people/ In fact, there are some of them not only headless but also having no heart/
The worse is their panakawan are alive completely with their head and heart/ That is the reality.]

A satire comedy is intentionally chosen by Riantiarno to persuade his audience to reflect on "the signs of local wisdom" which have been forgotten for long time. The dialogue quoted above reveals a kind of criticism. It may imply an interpretation about the authorities who are criticized for having no head and heart.

\section{Teater Koma and Its Audience}

Discussion on the sociology of art make us think a lot about impact of art to society, in which the art, in fact, deriving from society itself so does their opinion on art expression (Hauser, 2011: 89). Regarding this, Riantiarno explores ideas for his dramatic acts through the production of wayang kreatif which he created by building a new tradition. This is relevant to what is Hauser proposed especially when he urges that art can be derived from society and the emergence of opinions on art expression is also from society. The emerging opinion on art expression in the communication context can be categorized as a public opinion. The public opinion can be a general opinion or the opinion from a certain group in a society. In the context of Teater Koma, this public opinion comes from its supporting society as its loyal audience.

Based on the observation in research process, it can be concluded that the audience of Teater Koma really depends on what kind of plays that are performed. During their 40 years performances, there are also the proccess of the regeneration of its audience. There are three generations (grandfather, son/daughter, grandson/ granddaughter) who usually come together to the performance. This is surprising and satisfying at the same time for Teater Koma. ${ }^{16}$ Among the audiences, they are also people from high social class. One 
of them is a Chief Executive Officer (CEO) of a corporation who regularly attends the performance together with his family. They have been appreciating Teater Koma for fourteen years. The CEO enjoys watching Teater Koma because of social criticism and comedy in the performance. Unwittingly, the generation of Teater Koma audiences has changed. There are still people from the same generations with the performers or Riantiarno himself but most of them are younger generation. Later, this CEO will take all his children in their appropriate age to attend Teater Koma performance in which the dialogues are mostly for adult. ${ }^{17}$

There is also another note that since its presence in 1977, the audience of Teater Koma came from low and middle classes. Following the changes of the era which tends to a more consumptive way, there is a new phenomenon of Teater Koma audience. The audiences come from low, middle, and high classes. There are various people attending the performance, ranging from a young executive, a perfumed woman, trendy young man, and intellectuals. However, its loyal audience is handed down from generation to generation, from their fathers to their children. Further, in every performance there is always a new audience comes from general public, who does not really understand about a theatre performance. However, after several times attending to watch the performance soon he will be addicted to coming again and again. He chooses to watch Teater Koma instead of watching box office movies in a cinema. ${ }^{18}$

Moreover, Hauser (2011) stated that art could be considered as a product of society since a society has a taste to stimulate creators if the creators intend to do convergent communication or even to merge into a society. It can also be confirmed about the aesthetic dialectics built between creators, performances, and audience or public. The memory of early generations is then inhe- rited into next generations. Then, the later generations will also inherit it to the following generation, as can be seen in the context of three generations (grandfather, father, and son). Moreover, there are also audiences of Teater Koma performance from certain groups. They also have the same intention to inherit the "watching tradition" as their life style to their family.

Another aspect that has been done by Teater Koma in creating its audince is to utilize the link of social media for publication and to enable public to buy entrance tickets online. ${ }^{19}$ This is effective communication media. Teater Koma considers that building the tradition of watching is really important. Teater Koma's performance is not merely for art itself but also for urban society. This is because of the creative ideas are also taken from the problems of urban society. Therefore, they organize their move and performance with urban style. Although the group has different themes of plays, such as adaptation plays and selfcreated plays (wayang, Sampek Eng Tay, Si Jien Kwie), it finally invites public to build "the tradition of watching", which my turn into a loyal audience of Teater Koma.

\section{CONCLUSION}

From data analysis of the observation in this study, it can be concluded that Teater Koma is a modern theatre that has been survived for 40 years (1977 to 2017) where no many theatre groups can survive that long. Teater Koma has been passing through a long journey of activities and creativities of arts that is worth appreciating. This is a reason why Teater Koma is a worth resource of study for any researchers. There are so many issues which have not been written and recorded, let alone as a scientific writing.

Teater Koma can be a model of a modern theatre group, which is based their concept on various potential local Nusantara cultures such as sandiwara, lenong, topeng 
betawi etc. Teater Koma through its plays of wayang kreatif has been able to provide meaningful and enthusiastic of art appreciation for audience. Therefore, they can build "the tradition of watching" in three generations (grandfather, father, son). They also stimulate the growing of younger generation to know and to appreciate Teater Koma.

Teater Koma has never been leaving behind of their supporting society, especially Jakarta urban society. Fresh and smart humors arose from Riantiarno's wayang kreatif plays have contributed to enlightening, entertainment and escapism from working exhaustion of urban people.

In line with what is stated by Hauser (2011) that art can be considered as the product of society because it can spread inspiration from the creative procces of creators, which is in turn, will be given back to the society. Moreover, following Debord (1994), Teater Koma has been able to represent "the packed reality" in their art works. The works of wayang kreatif of Teater Koma are closed to their public experiences. In this regards, the effective communication concept of Gudykunst also shows that Teater Koma has proven itself as a modern theatre group with an effective communication model through its performences.

\section{End Note}

${ }^{1}$ Teater Koma was established in 1 March 1977 by twelve artists aimed to have different style of theatre performances. The main reason in forming the group was to find out other possibilities, a new way of performing on the stage. Teater Koma means teater tanpa selesai ("an unfinished theatre"). It is now 40 years old as an active modern theatre and productively performs good quality of performances.

${ }^{2}$ Carangan is a new form of a puppet play deriving from wayang plays (Mahabharata and Ramayana). This kind of play inspired by the richness of oral tradition existing in the wayang world wich is changed and modified creatively by puppeteers, both in a shadow puppet and a wayang golek, including by $\mathrm{N}$. Riantiarno with his Teater Koma. He wrote ten carangan plays.

${ }^{3}$ Wayang Wong is a form of folk theatre, which is popular among Javanese. This performance playing plays of Mahabharata dan Ramayana by humankind (wong=in Javanese meaning human). The group of wayang wong which still exists in Jakarta is the group of wayang wong Bharata.

${ }^{4}$ Interview with Ratna Riantiarno, a manager of Teater Koma, 20 September 2017 via Handphone.

${ }^{5}$ The writer has long interaction and friendship with the research resources, Nano Riantiarno and Ratna Riantiarno. The writer also meets them regularly every biennual working together as judges in the event of National Students Arts Festival (Festival Seni Mahasiswa tingkat Nasional/PEKSIMINAS). In this occassion, the writer dig more deeply their opinion both in subjective and objective manners about Teater Koma and its audiences.

${ }^{6}$ During 2015-2016 the research on Etnopedagogik Lakon Wayang dalam Produksi Pertunjukan Teater Koma has been conducted by Arthur S. Nalan, Retno Dwimarwati, and Yadi Mulyadi. This research is founded trough the fundamental research grant scheme from DP2M Kemenristekdikti.

${ }^{7}$ Teater Koma in its theatre works has been playing western plays and Chinese plays adapted into Indonesian contexts, and other plays written by $\mathrm{N}$. Riantiarno himself.

${ }^{8}$ Panakawan means witnessed friends. In the traditional wayang plays (Mahabharata, Ramayana and Lokapala) Panakawan is always presented. Panakawan has become inseparable characters in the performance accompanying the Knights characters. They have become attention of readers or audience, either good or bad Panakawan. See Sapardi Djoko Damono, Mengapa Kastria Membutuhkan Panakawan? (Essays), Jakarta: PascaIKJ, 2011.

${ }^{9}$ See Republik Wayang, wayang plays written by N. Riantiarno, Jakarta: Grasindo, 2016. The seven plays among others are: Republik Bagong, Republik Togog, Republik Petruk, Republik Cangik, Semar Gugat, Kala and Konglomerat Burisrawa.

${ }^{10}$ See Mahabharata Jawa, a wayang novel version of Riantiarno, Jakarta: Grasindo, 2016.

${ }^{11}$ See Wayang wong: Dramatari Ritual Kenegaraan di Keraton Yogyakarta, written by R.M. Soedarsono, Yogyakarta: Gadjah Mada Universiti Press, 1997.

${ }^{12}$ Sundanese drama Miss Tjitjih is a traditional theatre performing in Jakarta and is still appreciated by its supporting society, mostly by the Sundanese group living in Jakarta.

${ }^{13}$ Gayeng (Javanese language) means merrious, enjoyable, fun, and full of joke. See Kamus Jawa-Indonesia Populer, Purwadi, Yogyakarta: Media Abadi, 2004:122.

${ }^{14}$ Guyon Parikena is a concept of humor derived from Javanese. It is based on the word guyon meaning jokes; Parikena means suitable, reliable. Although the contents are sarcasm of criticism, guyon parikena will not make those who are critisized offended. Guyon parikena is one of Javanese local wisdom which is repromoted by Riantiarno in the plays of wayang kreatif he created.

${ }^{15}$ Sarkasme (sarcasm=ejekan, sindiran) the use of rough words to critisize or laugh at others. (Dagun, 2005: 1003).

${ }^{16}$ See an article, Koma yang tak mengenal titik, Republika co.id, 24 September 2017. It is note about Lian, a young audience who came with his father in Teater Koma performance Republik Cangik in Gedung Kesenian Jakarta, on Thursday (13/11). "My Dad said, the presence of this performances always eagerly awaited since long time ago. Since my dad was a student in Fine Art in Institut Kesenian Jakarta. I know more 
about this theatre group also from him," he said. (Accesed on 24 September 2017, at 14.00 PM).

${ }^{17}$ See Thomas Ekafitrianus, Gunawan: Suka Nonton Pentas Teater, bersatu.com. Wednesday, 23 April 2014. (Accessed on 24 September 2017, at 14.00 PM).

${ }^{18}$ Based on interview with Dorias, an active member of Teater Koma, an interview is conducted via Handphone, on 24 September 2017.

${ }^{19}$ The ticket fee is about 80 thousand to 240 thousand (Nomat, means nonton hemat or a special price), about 100 thousand to 300 thousand (weekday), about 150 thousand to 400 thousand (weekends and national holiday). See official Facebook of Teater Koma. (Accessed on 24 September 2017, at 14.00 PM).

\section{Bibliography}

Abercrombie, Nicholas, Stephen Hill, Bryan S. Turner

2010 Kamus Sosiologi. Yogyakarta: Pustaka Pelajar.

Arthur S. Nalan

2017 Dramawan \& Masyarakat: Paradigma Sosiologi Seni. Yogyakarta: Ombak.

Arthur S. Nalan, Retno Dwimarwati, Yadi Mulyadi

2016 Etnopedagogik Lakon Wayang dalam Produksi Pertunjukan Teater Koma, Hasil Penelitian Fundamental yang didanai DP2M Kemensitekdikti. Bandung: Institut Seni Budaya Indonesia (ISBI) Bandung.

Creswell, Jhon W.

2015 Penelitian Kualitatif \& Desain Riset: Memilih di antara lima pendekatan. Yogyakarta: Pustaka Pelajar.

Debord, Guy

1994 The Society of The Spectacle. New York: Zone Books.

Hauser, Arnold

1982 The Sociology of Art, translated by Kenet J. Northcott, London, Henley. Melbourne: Routledge, Kegan Paul.
Griffin EM (ed.)

2006 A First Look At Communication Theory. Sixth edition. New York: Mc Graw Hill.

Jenk, Chris

2013 Culture: Studi Kebudayaan. Yogyakarta: Pustaka Pelajar.

N. Riantiarno

2016 Republik Wayang: Kumpulan lakon wayang. Jakarta: Grasindo.

Purwadi

2004 Kamus Jawa-Indonesia Populer. Yogyakarta: Media Abadi.

R.M. Soedarsono

1997 Wayang wong: Drama tari Ritual Kenegaraan di Keraton Yogyakarta. Yogyakarta: Gadjah Mada University Press.

Sanderson, Stephen K.

2010 Makro Sosiologi: Sebuah Pendekatan Terhadap Realitas Sosial. Edisi kedua. Jakarta: PT. Raja Grafindo Persada.

Sapardi Djoko Damono

2011 Mengapa Ksatria Memerlukan Panakawan? Jakarta: PascaIKJ.

Save M. Dagun

2005 Kamus Besar Ilmu Pengetahuan. Jakarta: Lembaga Pengajian Kebudayaan Nusantara (LPKN). 